\title{
A new species of Elaphoglossum Schott ex J. Sm. (Dryopteridaceae) from Costa Rica
}

\author{
Alexander Francisco Rojas-Alvarado \& Pablo Elías Muñoz-Cambronero \\ Universidad Nacional de Costa Rica. \\ Apdo. 86-3000, Heredia, Costa Rica, C.A.
}

\section{Correspondence}

A. F. Rojas-Alvarado

e-mail: alfrojasa@yahoo.com

Recibido: 6 abril 2017

Aceptado: 29 agosto 2017

Publicado on-line: diciembre 2017

\section{Resumen \\ Una especie nueva de Elaphoglossum Schott ex J. Sm. Dryopteridaceae) para Costa Rica.}

Una especie nueva de Elaphoglossum Schott ex J. Sm de la sección Undulata Christ es descrita aquí: Elaphoglossum pallidosquamum A. Rojas \& P. Muñoz. La nueva especie es similar a $E$. herpestes por su rizoma largo ascendente, pero difiere por escamas del rizoma no cordadas basalmente (vs. cordadas) y más pálidas pardo-amarillentas con margen blanquecino o completamente blanquecinas (vs. castañas), escamas del estípite adpresas (vs. adpresas a moderadamente patentes) y más densas, lámina más angosta $2.5-4 \mathrm{~cm}$ de ancho (vs. 5-6.5 cm) con base anchamente cuneada a obtusa (vs. redonda), lámina con diferentes tipos de escamas las costales imbricadas (vs. distantes entre sí), escamas adaxiales densas (vs. dispersas), escamas abaxiales enrrolladas y moderadamente densas (vs. escamas abaxiales planas y dispersas) y, escamas marginales muy densas (vs. moderadamente densas a dispersas) y estas más pálidas blanquecinas a amarillo pálido (vs. pardas).

Palabras clave: Eupolipodios, helechos, Polypodiales, Pteridophyta, sección Undulata.

\begin{abstract}
A new species of Elaphoglossum Schott ex J. Sm of section Undulata Christ is described here: Elaphoglossum pallidosquamum A. Rojas \& P. Muñoz. The new species is similar to $E$. herpestes because of its long ascending rhizome, but differs by its not chordate (vs. chordate) basally and paler rhizome scales brown-yellowish with whitish margin or fully whitish (vs. castaneous), appressed (vs. appressed to moderately patent) and more dense stipe scales, narrower blade $2.5-4 \mathrm{~cm}$ broad (vs. 5-6.5 cm) with broadly cuneate to obtuse base (vs. rounded), blade with different scale types costa with imbricate scales, dense and flat adaxial scales, moderately dense and enrolled abaxial scales and very dense marginal scales (vs. all scales similar except for denser in midvein) and they are paler whitish to pale yellow (vs. brown).
\end{abstract}

Key words: Eupolypods, ferns, Polypodiales, Pteridophyta, section Undulata.

\section{Introduction}

Mickel(1995) described the genus Elaphoglossum Schott ex J. Sm. by its simple blade rarely pedate or cristate), free veins and acrostichoid sori.
Mickel \& Atehortúa (1980) divided the genus in nine sections. The section Undulata Christ was defined by short creeping to erect rhizome; absence of phyllopodia; ovate-lanceolate blade; subulate to deltate-lanceolate, erose or toothed blade 
scales; conspicuous hydathodes; spores without ridges, openly reticulate-equinate, the spine bases diverging and forming a reticulum occasionally with irregular verrucae or perforated crests. Rouhan et al. (2004), in their phylogenetic analyses, found that the section Undulata is part of the section Setosa (Christ) Mickel \& L. Atehortúa. However, because the authors decided not to describe the aberrant clades as new taxa, it is assumed that further studies are required to establish a new classification system.

Mickel (1985) mentioned that many proliferous species are included in section Undulata or section Setosa (Christ) Mickel \& Atehortúa, but principally in the first one.

In the last four decades several new species of section Undulata have been described such

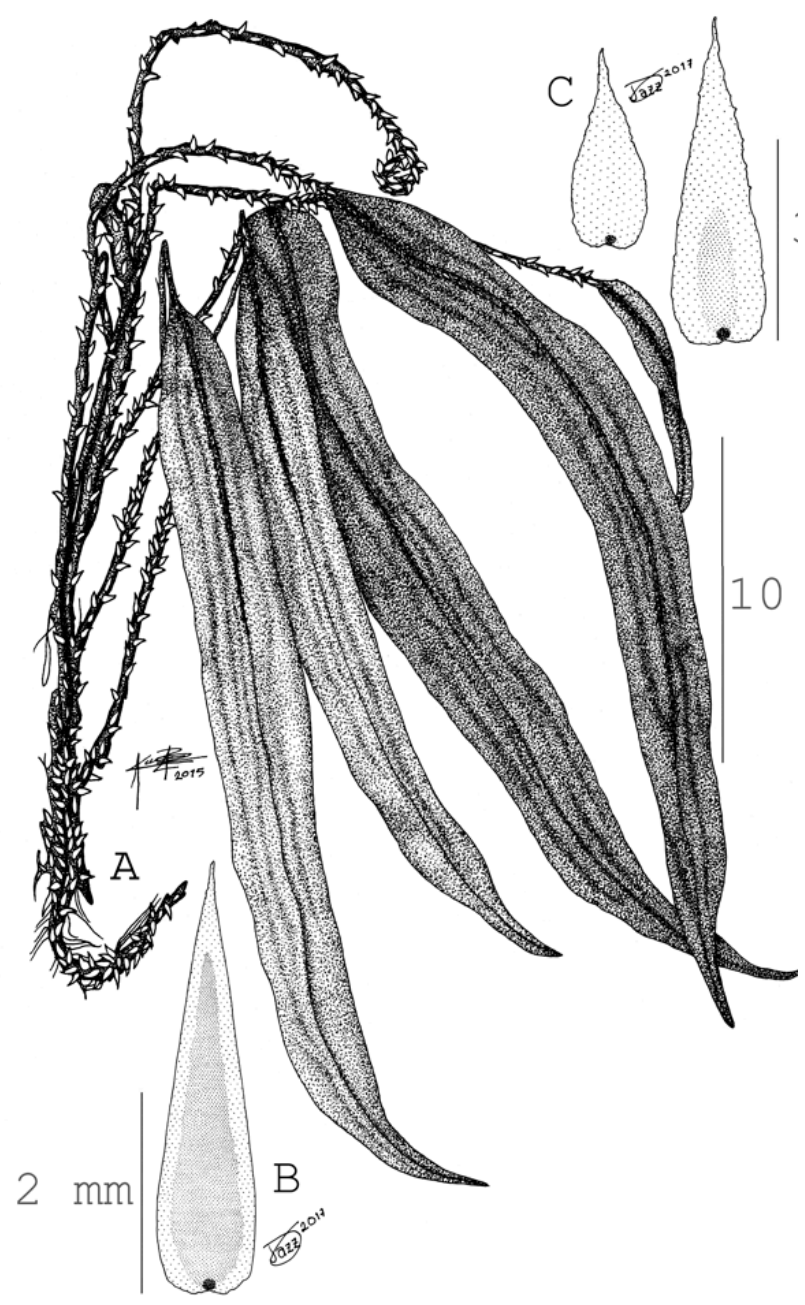

Figure 1. Elaphoglossum pallidosquamum (A. Rojas \& P. Muñoz 11254, CR): A. Habit. B. Rhizome scale. C. Stipe scales. Figura 1. Elaphoglossum pallidosquamum (A. Rojas \& P. Muñoz 11254, CR): A. Hábito. B. Escama del rizoma. C. Escama del estípite. as: Mickel (1985, 1987, 1991, 1992, 1993), Rojas (1996), Rojas \& Rodríguez (2012) and Vasco (2006). In this work a new species is described.

\section{Materials and methods}

The new species here described is the result of comparisons of specimens with collections from Costa Rica deposited in the National Herbarium (CR), and of the revision of related species and keys from the Neotropics such as: Gómez \& Arbeláez (2009), Mickel (1995), Mickel \& Smith (2004) and Murillo et al. (2008).

\section{Results}

Elaphoglossum pallidosquamum A. Rojas \& $\mathrm{P}$. Muñoz, sp. nov. (fig. 1, 2).
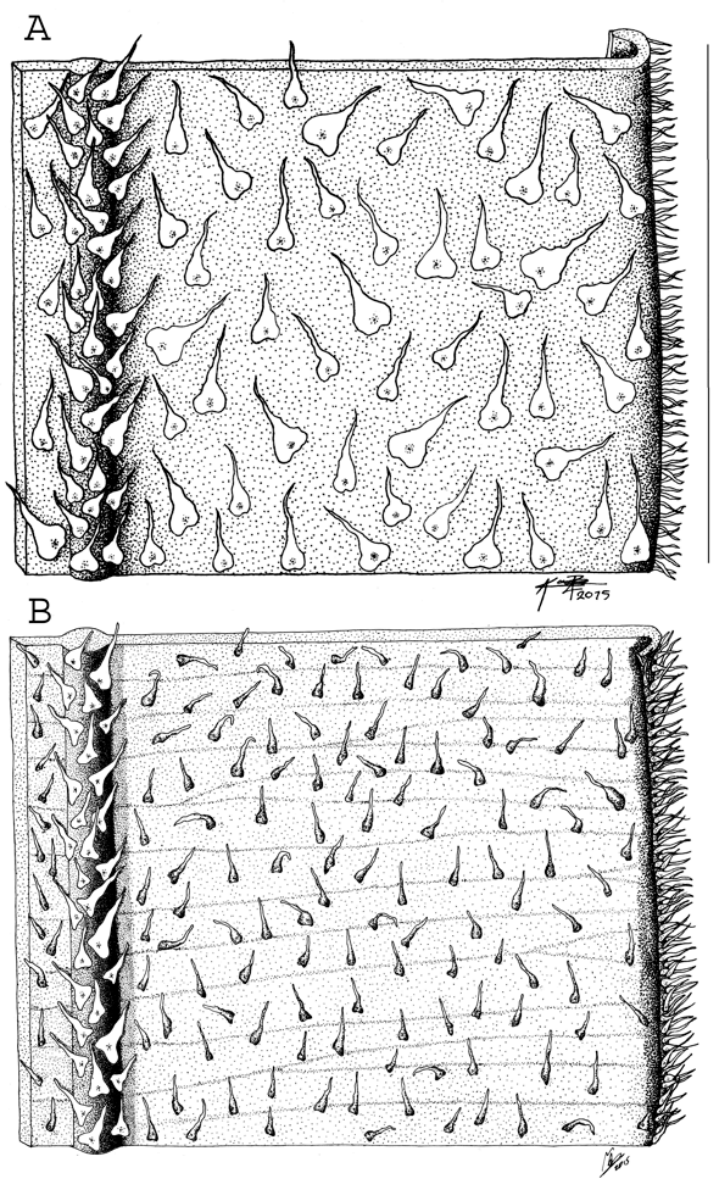

Figure 2. Elaphoglossum pallidosquamum (A. Rojas \& P. Muñoz 11254, CR): A. Adaxial blade detail; B. Abaxial blade detail. Figura 2. Elaphoglossum pallidosquamum (A. Rojas \& P. Muñoz 11254, CR): A. Detalle adaxial de la lámina; $B$. Detalle abaxial de la lámina. 
TYPE: COSTA RICA. San José: Dota, Carretera Interamericana, entre los $\mathrm{km} 72$ y 73, orillas de quebrada, $9^{\circ} 37^{\prime} 58^{\prime \prime} \mathrm{N}, 83^{\circ} 50^{\prime} 33^{\prime \prime} \mathrm{W}, 2850-$ 2900 m, 12 jul 2015, A. Rojas \& P. Muñoz 11254 (holotype: CR 282817; isotypes: 3 duplicates will be distributed).

Diagnoses. Differs from Elaphoglossum herpestes Mickel by its terrestrial habitat, paler and no cordate basally rhizome scales, adpressed and denser stipe scales, narrower blades with broadly cuneate to obtuse bases, paler blade scales and enrolled abaxial blade scales.

Description. Terrestrial; rhizome $4-7 \mathrm{~mm}$ in diameter, creeping to ascending; rhizome scales 1.5-4 × 0.5-2 mm, ovate-acuminate, brownyellowish with whitish margin or fully whitish, flat, adpressed, very dense, rounded at base, attenuate at apex, entire at apex; fronds $36-52 \mathrm{~cm}$ long, 2-6 cm appart; phyllopodia absent; stipe 1/3-1/2 of the frond length; stipe scales 3-5 $\times 0.5-2 \mathrm{~mm}$, ovate to lanceolate, whitish to pale yellow, sometimes with brown center, moderately adpressed, rounded at base, attenuate at apex, entire at margin; blade 24.5-32 × 2.5-4 cm, linear-elliptic, chartaceous, broadly cuneate to obtuse at base, acute to acuminate at apex, entire and undulate at margin, scaly in both surfaces; adaxial blade scales 2-2.5 $\times 0.5-1.0 \mathrm{~mm}$, ovate to lanceolate, expanded at base, withish to pale yellow, attached point brown, appressed, flat, but marginal scales slightly enrolled near the attached point to blade, rounded at base, attenuate at apex, denticulate at margin; abaxial blade scales $0.5-1.0 \times 0.25-0.3 \mathrm{~mm}$, lanceolate to linear-lanceolate, enrolled at base, pale brown to brown-reddish with paler apex, rounded at base, attenuate at apex, sparsely denticulate at margin; costal scales $2.0-3.0 \times 0.5-0.75 \mathrm{~mm}$, lanceolate, whitish to pale yellow, flat, expanded at base, acute at apex, sparsely denticulate at margin; blade margin scales 1.0-1.5 × 0.25-0.75 mm, linear to subulate with enrolled base, pale brown to pale brown-reddish, rounded at base, acuminate at apex, sparsely dentate at margin; hydathodes present; fertile fronds $23-36 \mathrm{~cm}$ long; stipe 3/5-3/4 of the frond length; fertile blade 5.5-12.5 × 1.0-2.0 $\mathrm{cm}$, lanceolate, cuneate and enrolled at base, acute at apex, flat; intersporangials scales 0.75$1.0 \times 0.1-0.25 \mathrm{~mm}$, lanceolate with enrolled base, brown-yellowish, sparsely denticulate at margin.

Distribution. Only in the Caribbean side of Cordillera de Talamanca in Costa Rica and Cordillera de Los Andes in Ecuador at 2850-3200 $\mathrm{m}$.
Etimology. The name of this new species make reference to scales coloration, which are pale.

Additional revised specimens. COSTA RICA. San José: Dota, Carretera Interamericana, entre los $\mathrm{Km} 72$ y 73 , orillas de quebrada, $9^{\circ} 37.897^{\prime} \mathrm{N}$ 8350.607'W, 2850-2900 m, 10 abr 2015, A. Rojas \& F. Villalobos 11032 (CR, 282818, 3 duplicates will be distributed).

ECUADOR. Napo: Cerro Sumaco, 3200 m, 27 Apr 1979, M.T. Madison 6866 (SEL, 26863).

\section{Discussion}

Elaphoglossum pallidosquamum differs from E. herpestes Mickel by its terrestrial (vs. epiphytic) habitat, non cordate (vs. cordate) basally and paler rhizome scales (brown-yellowish with whitish margin or fully whitish vs. castaneous), adpressed (vs. adpressed to moderately patent) and denser stipe scales, narrower blades $(2.5-4 \mathrm{~cm}$ broad vs. $5-6.5 \mathrm{~cm}$ ) with bases broadly cuneate to obtuse (vs. rounded), blades scales of different types (imbricate vs. distant costal scales, scales dense vs. sparse adaxial, enrolled and moderately dense vs. flat abaxial scales and marginal scales sparse and very dense vs. all scales similar except for denser scales in midvein) and different in color (whitish to pale yellow vs. brown) figs. 1, 2).

\section{Acknowledgments}

This work has been possible thanks to the Vicerrectoría de Investigación of Universidad Nacional de Costa Rica (UNA) and Sistema Nacional de Áreas de Conservación (SINAC). Also thanks to the Herbario Nacional de Costa Rica (CR) for the specimen loans and the space to study the specimens, to Karen Bermúdez Barrantes and Jasmín Mejía Vargas for the excellent illustrations, to the anonymous reviewers for their suggestions; and to all who, in one way or another, made this work possible.

\section{References}

Gómez, L. D., \& Arbeláez, A. L. (2009). Flora de Nicaragua. Tomo IV: helechos. St. Louis, Missouri: Missouri Botanical Garden.

Mickel, J. T. (1985). The proliferous species of Elaphoglossum (Elaphoglossaceae) and their relatives. Brittonia, 37, 261-278.

Mickel, J. T. (1987). New species of Elaphoglossum Elaphoglossaceae) from northern South America. Brittonia, 39, 313-339.

Mickel, J. T. (1991). Elaphoglossum. In RM Tryon \& RG Stolze (Eds.), Pteridophyta of Peru. Part IV. 17. Dryopteridaceae (pp. 111-166). Fieldiana Botany, 
new series, 32.

Mickel, J.T. (1992). New species of the fern genus Elaphoglossum from Mesoamerica. Novon, 2, 368382.

Mickel, J.T. (1993). Six new species of Elaphoglossum (Elaphoglossaceae). Brittonia, 45, 213-218.

Mickel, J.T (1995). Elaphoglossum. In RC Moran, R Riba (Eds.), Flora Mesoamericana: Volumen 1. Psilotaceae a Salviniaceae. México D. F.: Universidad Nacional Autónoma de México.

Mickel, J.T., \& Atehortúa, L. (1980). Subdivision of the genus Elaphoglossum. American Fern Journal, 70, 47-68.

Mickel, J.T., \& Smith, A. R. (2004). The Pteridophytes of Mexico. Memoirs of the New York Botanical Garden, 88, 1-1029.

Murillo, M.T., Murillo, J., León, A. \& Triana, L.A. (2008).
Los Pteridófitos de Colombia. Bogotá, D.C. Arfo.

Rojas, A.F. (1996). Twelve new species of Elaphoglossum from Costa Rica and Panama. Brenesia, 45-46, 7-26.

Rojas, A.F., \& Rodriguez, W.D. (2012). Dos especies nuevas de Elaphoglossum Schott ex J. Sm. (Dryopteridaceae) prolíferos para Colombia. Actualidades Biológicas, 34, 183-186.

Rouhan, G., Dubuisson, J.Y., Rakotondrainibe, F., Motley, T.J. , Mickel, J.T., Labat, J.N. \& Moran, R.C. (2004). Molecular phylogeny of the fern genus Elaphoglossum (Elaphoglossaceae) based on chloroplast non-coding DNA sequences: contributions of species from the Indian Ocean area. Molecular Phylogenetics and Evolution, 33, 745-763.

Vasco, A. (2006). Elaphoglossum gemmatum (Elaphoglossaceae), a new species from Colombia. Brittonia, 58, 1-3. 